\title{
Production and Economic Characteristics of Intensive and Semi- Intensive Dairy Cattle Management Systems in Vegetable Based Farming System in Welimada, Sri Lanka
}

\author{
D.M.D.S. Bandara, S. Premaratne ${ }^{{ }^{*}}$ and C.M.B. Dematawewa ${ }^{1}$ \\ Postgraduate Institute of Agriculture \\ University of Peradeniya \\ Sri Lanka
}

\begin{abstract}
The objective of this study was to identify and compare different dairy cattle management systems in vegetable based farming system in Welimada division in Badulla district (up country wet and intermediate zones) with respect to their production and economic characteristics. Data were collected from 92 randomly selected vegetable based dairy farmers using a structured questionnaire and milk payment registers of milk collectors. Means of various production and economic parameters of management systems were compared. Intensive and semi-intensive management systems were present in Welimada area. Twenty six \% of dairy farmers had primary education and $64.6 \%$ had studied up to GCE $(O / L)$ while the rest had completed GCE (A/L). Educational background had no significant effect on the income of farmers from dairying. Mean herd sizes of intensive and semi-intensive management systems were 4.1 and 3.2 animal units (AU), respectively. Compared to semi-intensive system, intensive system was significantly lower $(P<0.05)$ in post-weaning mortality and higher $(P>0.05)$ in milk yield per herd, income and labour and other costs (concentrates, drugs and services) per herd leading to non significant $(P>0.05)$ profit differences. Net returns per herd (excluding labour cost) were Rs. 281 and 177 per day for intensive and semi-intensive systems, respectively. When labour cost was not included in profit calculation, the mean net income per day per AU received by the farmers under intensive system was higher $(P>0.05)$ compared to semi-intensive system. Introduction of good manure management practices and establishment of good quality pasture and fodder in the contour lines of the farm as well as a fence line would help to reduce the labour cost for cutting grass and expenses for concentrate feeding while increasing the profit. Upgrading of animals can also lead to higher production in the herd under a semi-intensive system.
\end{abstract}

Key words: Dairy cattle production, management systems, up country wet and intermediate zones.

\section{INTRODUCTION}

The need for expansion of dairy production in Sri Lanka is a necessity as the country depends largely on imports to fulfil the domestic demand for milk and dairy products. According to Livestock Statistics, 2009 report, amount of milk and milk product imports to Sri Lanka up to the third quarter of 2009 was $95,199,916 \mathrm{~kg}$ which was worth Rs. $28352 \mathrm{mn}$. It is inevitable that the dependency on milk imports will continue in future. Therefore, it is

To whom correspondence should be addressed: suep@pdn.ac.lk

Department of Animal Science, Faculty of Agriculture, University of Peradeniya, Peradeniya, Sri Lanka 
important to assess the strengths and weaknesses of prevailing dairy cattle management systems in the country so that short term and long term measures can be taken to improve the milk production in the country.

In the Badulla district, dairy farming is an important traditional economic activity where it is mostly integrated with small-scale vegetable cultivation through utilization of cattle manure. The climatic condition of Badulla district (up country wet and intermediate zones) is favourable for dairy farming activities, and $9 \%$ of contribution to the total milk production of Sri Lanka is provided by the Badulla district (Progress Review Report, Department of Animal Production and Health, Uva Province, 2008). Several studies have shown that up country farmer had to spend a higher percentage of total cost of production on labour and concentrates due to intensive/semi-intensive farming and less forage availability in the area (Rathnayake et al., 1992; Mahipala and Gunaratne, 2003; Serasinghe et al., 2003; Mahipala et al., 2006).

The main milk collectors of Badulla district are MILCO (Pvt.) Ltd. and Nestle Lanka (Pvt.) Ltd. The competition between the collectors has led to a reasonable farm gate price for milk. Badulla district consists of six Divisional Secretariat divisions namely Badulla, Haliela, Welimada, Bandarawela, Ella and Haputale. At present, the second highest milk production in Badulla district is reported from Welimada division (Progress Review Report, Provincial Department of Animal Production and Health, Uva Province, 2008).

The main objective of the present study was to investigate the characteristics of available management systems in village based farming system in Welimada Divisional Secretariat in Badulla district and to estimate expenses and income of dairy farming under different management systems.

\section{METHODOLOGY}

A randomly selected set of 92 vegetable based dairy farmers in Welimada Divisional Secretariat was used to collect data on management systems by using a pre-tested structured questionnaire, from January 2007 to June 2008. The questionnaire consisted of socio economic information about the farmer, labour usage by the farmer, gender contribution on dairying, herd composition, breeds/crosses and production performance of animals, availability of feed stuffs, and economic returns from dairying. In addition, milk payment registers of milk collection institutes were also used to gather information.

The questionnaires were entered into spreadsheets and statistical analysis was carried out using SAS software (SAS, 1998). For determination of herd size, adult cows and bulls were considered as single animal units and suckling calves (1-8 weeks), weaners (2-12 months) and heifers (1-2 years) were considered as $0.35,0.40$ and 0.87 animal units (AU), respectively. The income generated by selling milk, manure and additional animals was considered in estimating total income. The fixed costs associated with animals, land, buildings and other capital investments, and depreciation were not considered in estimating total expenditure. Profits were calculated on daily basis including as well as excluding labour cost. For each production or economic parameter and other input/output measurements, the respective means of the two systems were compared using t-test. Significance of associations between pairs of relevant categorical variables was determined using Chi-square test. 


\section{RESULTS AND DISCUSSION}

The farms having animals kept in the sheds for $24 \mathrm{~h}$ while supplying feed and (zero grazing) were classified as intensive system. Under semi-intensive system, animals were tethered at about 8.00 a.m. after morning milking and brought back to the sheds around 2.30 p.m. Night feeding was practised commonly in both systems. Extensive system was not practised in the surveyed area due to limited availability of free grazing areas and to avoid possible damage to vegetable cultivation. According to the survey about $22 \%$ of the farmers practised intensive system while the rest belonged to semi-intensive system.

\section{Effect of educational background}

The results of the survey showed that approximately $25.6 \%$ of dairy farmers completed primary education while about $64.6 \%$ had studied up to GCE $(\mathrm{O} / \mathrm{L})$. Only about $9.8 \%$ of the farmers had completed GCE (A/L) while no farmer had undergone tertiary education. The above results are in agreement with those reported by the Department of Census and Statistics (2006) for the whole agriculture sector in Welimada division where $7.2 \%$ of agricultural operators had passed GCE (A/L) while 23.7\% had obtained GCE (O/L) qualifications.

The results indicated that a slightly higher percentage of farmers with primary education $(81 \%)$ had practiced semi-intensive farming than farmers with $\mathrm{A} / \mathrm{L}$ education (75\%) but Chisquare analysis conducted between level of education and the management system adopted showed that those minor differences were not significant $(\mathrm{P}>0.05)$ indicating no association between level of education and choice of management system by the dairy farmers. These results are in agreement with the results of Mahipala and Gunaratne, 2003, where $76 \%$ of dairy farmers in estate based system and $64 \%$ of farmers in village based system completed the primary education in Nuwara Eliya district (up country wet zone).

According to the survey results, dairying was the primary source of income of $47.6 \%$ of the farmers while for the rest, vegetable cultivation was predominantly the main income source. Many of the dairy cattle farmers with $\mathrm{A} / \mathrm{L}$ qualifications did not consider dairying as a primary source of income (38\%) whereas more of those with lesser education considered it as their primary employment (47-49\%). However, Chi-square analysis conducted between level of education and source of income indicated that the level of education had no significant association with the farmers considering dairying as their primary source of income or not $(\mathrm{P}>0.05)$. Finally, the means of total income (Rs. per month) of farmers having education levels namely grade $1-5$, grade $6-\mathrm{O} / \mathrm{L}$, and $\mathrm{A} / \mathrm{L}$ were $6943.00 \pm 830.74$ $7520.00 \pm 808.35$ and $6479.00 \pm 1781.60$, respectively. However, analysis of variance carried out showed that the above means were not significantly different $(\mathrm{P}>0.05)$. The possible reasons for lack of significance in this study may be that the total income of a farm depends more on herd size, management system and other factors that are directly a function of total income than the level of education, which has an indirect impact on economics of the enterprise.

\section{Management systems}

As indicated previously, only about $1 / 4$ th of the dairy cattle farmers in Welimada division managed animals on zero grazing. Sixty one percent of the intensive system based farmers were engaged on dairying on full time basis while only $43.7 \%$ of the semi-intensive farmers were full time dairymen. However, Chi-square analysis showed that the difference in the 
above percentages was not significant $(\mathrm{P}>0.05)$. MILCO and Nestle Companies have established an efficient milk collection network in Walimada division so that milk was collected twice. MILCO Company operated through farmer managed societies (FMS) while Nestle Company had received milk through private collectors operating on distinct routes.

The number of animals present in each age group (calves, weaners, heifers, cows and bulls were compared between the two systems using t-test (Table 1). Mean number of weaner calves (8-12 $\mathrm{m}$ of age) was higher under intensive system compared to semi-intensive system $(\mathrm{P}<0.05)$. The farmers of both intensive and semi-intensive systems reared calves up to 8 weeks of age (up to weaning) in the shed so that they had a controlled environment. However, under semi intensive system, calves were tethered outside after weaning at 8 weeks of age. As a result, the weaned calves under semi-intensive system frequently suffered from pneumonia, tick fever (Babeciosis), anaemia, photosensitisation, and gastro-intestinal parasite infestations. Since the outdoor grazing areas were infested with eggs and larval stage of many external (ticks etc.) and internal (e.g. round worms such as haemoncus spp, bunostormum spp) parasites, the weaner calves in semi intensive system got parasitic infestations rapidly leading to tick fever, diarrhoea and anaemic conditions. These results are in agreement with the Epidemiological Report, Veterinary Office, Welimada, 2008 and Investigation Report of Veterinary Investigation Centre, Badulla, 2009. Exposure to bad weather conditions and bacterial infections on respiratory system also frequently caused pneumonia in weaners. All of the above conditions lead to higher post weaning calf mortality under semi-intensive system.

Table 1. Effect of management system on herd composition

\begin{tabular}{lcc}
\hline Herd composition & Intensive & Semi-intensive \\
\hline Calves (before $2 \mathrm{~m})$ & $1.28^{\mathrm{a}} \pm 0.22$ & $0.95^{\mathrm{a}} \pm 0.11$ \\
Weaned calves $(2-12 \mathrm{~m})$ & $0.78^{\mathrm{a}} \pm 0.22$ & $0.26^{\mathrm{b}} \pm 0.06$ \\
Heifers & $0.67^{\mathrm{a}} \pm 0.24$ & $0.67^{\mathrm{a}} \pm 0.10$ \\
Cows & $2.6^{\mathrm{a}} \pm 0.36$ & $1.95^{\mathrm{a}} \pm 0.15$ \\
Bulls & $0.28^{\mathrm{a}} \pm 0.11$ & $0.34^{\mathrm{a}} \pm 0.10$ \\
\hline
\end{tabular}

Means with different superscripts in a column are significantly different $(\mathrm{P}<0.05)$.

The mean herd sizes of the two management systems were not significantly different $(\mathrm{P}>0.05)$ even though the herd size under intensive system was higher compared to semiintensive system (Table 2). According to Mahipala and Gunaratne (2003), total herd size $(2.59 \mathrm{CU})$ and number of milking cows $(1.39 \mathrm{CU})$ under milk based farming system (Estate based system-Intensive system) was lower compared to vegetable based system (Semiintensive system) (Herd size 3.32 CU and number of milking cows $2.06 \mathrm{CU}$ ) in NuwaraEliya district. As mentioned earlier, the present study was conducted at Welimada area using vegetable based system farmers whereas Mahipala and Gunaratne, 2003 used farmers from vegetable based system as well as from milk based or estate based system. Therefore, the results of this study are not in agreement with the work of Mahipala and Gunaratne, (2003).

\section{Milk production}

The results of comparisons made between the two systems with respect to mean milk production per herd, number of days in production and mean milk production per cow (using t-test) are shown in Table 2. Characteristically, none of the intensive farms in Welimada division were large farms and, the largest intensive farm had only 7.6 animal units. The mean 
herd sizes of the two systems were not significantly different $(\mathrm{P}>0.05)$ indicating that all full time and part time dairy farmers in the division operate on a small scale regardless of the management system.

In both systems, there were farms which had zero milk in some periods of the year, partly because of small herd size, lack of milking cows and shorter lactation lengths. The mean milk production per herd was significantly higher $(\mathrm{P}<0.05)$ in intensive system compared to semi-intensive system, partly because of the slightly larger (though non significant) herd size, production periods and milk yields of animals in intensive system. In intensive system, almost all farms consisted of either pure Friesian or pure Jersey animals while in semiintensive farms, about $30 \%$ of the animals were European crosses while $70 \%$ were pure bred animals. Consequently, mean milk yield per cow was slightly higher in intensive farms than that of semi-intensive farms though the figures were not significantly different $(\mathrm{P}>0.05)$. These results are similar to those found on Kandyan Forest Gardens (Zemmelink et al., 1999). However, according to Mahipala and Gunaratne, 2003, milk production under milkbased system (Intensive) was lower $(\mathrm{P}<0.05)(7.05 \mathrm{~kg} / \mathrm{cow} /$ day $)$ compared to Vegetablebased system ( $8.205 \mathrm{~kg} / \mathrm{cow} /$ day) in Nuwara Eliya district. This difference may be related to the use of different farming systems in Nuwara-Eliya district compared to two management systems within the same farming system used in the present study (Mahipala and Gunaratne, 2003) and, the different climatic conditions in two districts.

Table 2. Effect of farming system on herd size and milk production

\begin{tabular}{lrr}
\hline Herd size/Milk production & Intensive & \multicolumn{1}{c}{ Semi-intensive } \\
\hline Herd Size (AU) & $4.10^{\mathrm{a}} \pm 0.50$ & $3.20^{\mathrm{a}} \pm 0.24$ \\
Milk yield (L/month/herd) & $433.70^{\mathrm{a}} \pm 66.2$ & $255.70^{\mathrm{b}} \pm 20.20$ \\
No. of days milked per year & $310.11^{\mathrm{a}} \pm 32.24$ & $302.28^{\mathrm{a}} \pm 29.10$ \\
Milk yield (L/cow/d) & $5.80^{\mathrm{a}} \pm 0.49$ & $4.90^{\mathrm{a}} \pm 0.40$ \\
\hline
\end{tabular}

Means with different superscripts in a column are significantly different $(\mathrm{P}<0.05)$.

$1 \mathrm{AU}=$ One animal unit of $300 \mathrm{~kg}$ animal.

\section{Supplementary feeding}

The FMS established under MILCO provided only compound cattle feed for farmer members for a minimal price of Rs 19.50 per kg. The farmers who sell their milk to the private collectors appointed by Nestle did not receive the above compound feed. However, those private collectors supplied rice bran and coconut poonac and cost of the supplied items was deducted from the milk payments at the end of every month. The survey showed that mean cost for concentrates in intensive farming system was Rs. 107.63 per day per herd and this figure was significantly higher than the mean cost under semi-intensive system (Rs. 46.14 per day per herd). These results are in agreement with the findings of previous studies (Zemmelink et al., 1999; Bandara, 2000; Jayaweera et al., 2003; Perera et al., 2004; Ranaweera, 2007 and Hitihamu et al., 2007).

Most of the farmers in both management systems used natural grasses as the main feed source to feed their animals. All the farmers fed Glyricidia (Glyricidia provenances) and jak (Artocarpus heterophylus) leaves to their animals. Few farmers grew improved varieties of grasses in their land which were distributed by the Veterinary Surgeon. However, rice straw was not given to animals in Welimada area. 


\section{Labour usage}

The man hours of labour used daily for cleaning of the sheds, milking, grass cutting, and carrying of milk to collecting points or centres were estimated by interviewing the farmers (Table 3). As animals (except suckling calves) are tethered during the day, the farmers under semi-intensive system required grass cutting only for night feeding. Therefore the labour usage for grass cutting was significantly lower in semi-intensive system $(\mathrm{P}<0.05)$ compared to intensive system. The slightly higher values of labour use for cleaning the sheds under intensive system were because of more time spent by the cows in sheds and consequently higher accumulation of cow dung, etc. The higher labour use for milking was probably because of slightly higher number of cows and more time required for cleaning udders. However, both of those differences were not statistically significant $(\mathrm{P}>0.05)$. These results are in agreement with those found in small holder systems of other regions of Sri Lanka as well (Den Dikken, 1997; Ministry of Livestock Development and Estate Infrastructure, 2000)

Table 3. Effect of farming system on usage of labour for dairying (man h/day)

\begin{tabular}{lcc}
\hline Usage of labour & Intensive & Semi-intensive \\
\hline Grass cutting & $7.20^{\mathrm{a}} \pm 0.62$ & $5.10^{\mathrm{b}} \pm 0.34$ \\
Cleaning the shed & $0.95^{\mathrm{a}} \pm 0.15$ & $0.76^{\mathrm{a}} \pm 0.05$ \\
Milking & $0.63^{\mathrm{a}} \pm 0.06$ & $0.55^{\mathrm{a}} \pm 0.03$ \\
Sale of milk & $0.64^{\mathrm{a}} \pm 0.14$ & $0.85^{\mathrm{a}} \pm 0.06$ \\
Total & $9.52^{\mathrm{a}} \pm 0.67$ & $.7 .35^{\mathrm{b}} \pm 0.40$ \\
\hline
\end{tabular}

Means with different superscripts in a column are significantly different $(\mathrm{P}<0.05)$.

Since the labour requirement was more in intensive system, amount of money spent on labour was also higher $(\mathrm{P}<0.05)$ under intensive system compared to semi-intensive system (Table 4). The total cost figures were in fact an under estimation of the true values as other items of expenditure such as capital, depreciation, repairs, equipment, etc. were not included.

Table 4. Effect of farming system on usage of labour per day (Rs. /d)

\begin{tabular}{lrr}
\hline Usage of labour & \multicolumn{1}{c}{ Intensive } & \multicolumn{1}{c}{ Semi-intensive } \\
\hline Grass cutting & $341.22^{\mathrm{a}} \pm 30.52$ & $239.50^{\mathrm{b}} \pm 15.63$ \\
Cleaning the shed & $43.80^{\mathrm{a}} \pm 6.33$ & $35.05^{\mathrm{a}} \pm 2.35$ \\
Milking & $29.70^{\mathrm{a}} \pm 3.07$ & $25.00^{\mathrm{a}} \pm 01.30$ \\
Sale of milk & $30.18^{\mathrm{a}} \pm 6.73$ & $39.62^{\mathrm{a}} \pm 3.19$ \\
Total & $444.93^{\mathrm{a}} \pm 32.86$ & $339.68^{\mathrm{b}} \pm 18.30$ \\
\hline
\end{tabular}

Means with different superscripts in a column are significantly different $(\mathrm{P}<0.05)$.

Establishment of good quality pasture or fodder in the farm may help to reduce the labour cost for grass cutting and, expenses for concentrate feeding while increasing the profit. Grasses are being used to control soil erosion in vegetable land in Welimada area and, quality pasture can replace these contour lines and thereby produce high quality feeds for dairy cattle in these systems. In addition, fodder legumes can be grown under SALT system or as a fence line so that farmers could use it as forage for ruminants. Use of rice straw or treated straw can be promoted in the area so that it can be fed during the drought or when other feeds are lacking in the area. 


\section{Gender contribution}

The percentage of labour shared by males and females for each farm activity are given in Table 5. Chi-square analysis showed that those percentages were not significantly different $(\mathrm{P}>0.05)$ indicating that males and females share every activity of dairy operation equally regardless of the management system. However, grass cutting and shed cleaning were done by males compared to females even though the values were not significantly different $(\mathrm{P}>0.05)$.

Table 5. Gender contribution of dairy farming (\%)

\begin{tabular}{lcccccccc}
\hline Farming system & \multicolumn{2}{c}{ Grass cutting } & \multicolumn{2}{c}{ Cleaning the shed } & \multicolumn{2}{c}{ Milking } & \multicolumn{2}{c}{ Sale of milk } \\
\hline & $\mathrm{M}$ & $\mathrm{F}$ & $\mathrm{M}$ & $\mathrm{F}$ & $\mathrm{M}$ & $\mathrm{F}$ & $\mathrm{M}$ & $\mathrm{F}$ \\
Intensive & 58.5 & 41.2 & 57.1 & 42.9 & 57.9 & 42.1 & 50.0 & 50.0 \\
Semi-Intensive & 51.1 & 48.9 & 53.8 & 46.2 & 43.8 & 56.2 & 51.6 & 48.4 \\
\hline
\end{tabular}

$\mathrm{M}=$ male and $\mathrm{F}=$ female.

\section{Net income}

Animals were sold at an average of Rs. 30000.00 per head (Rs.100 kg of live weight). However, only seven animals were sold by both systems combined during the 1.5 years of survey period. Value of labour was considered as Rs. 450.00 for males and Rs. 350.00 for females per day ( $8 \mathrm{~h}$ of work) as the average figures in Welimada region during the period of the study. Income from manure was considered as Rs. 3000.00 per tipper load ( 250 cubic feet, Rs. 12.00 per one cubic feet) during the year 2008. Table 6 clearly shows that total income from dairying was significantly higher $(\mathrm{P}<0.05)$ under intensive system compared to semi-intensive system. This is the cumulative result of slightly larger herd size, higher proportion of purebred animals and better feeding practices used under intensive system compared to semi-intensive system in the present study.

During the survey period of 18 months, the percentages of income received by intensive farmers from selling milk, manure and excess animals were $82.6 \%, 15.0 \%$, and $2.4 \%$, respectively whereas the corresponding figures for semi-intensive farms were $89.0 \%, 9.9 \%$, and $1.1 \%$, respectively. Farmers under the semi-intensive system lost the opportunity to gather the full amount of cow dung produced by their cows due to tethering outside their farm area. Consequently, the income generated from cattle manure by the intensive farms was significantly higher $(\mathrm{P}<0.05)$ than semi-intensive farms. The primary income source from the majority of dairy farms was milk production.

Table 6. Effect of management system on income from dairying (Rs. /month/herd)

\begin{tabular}{lrr}
\hline Income & Intensive & Semi-intensive \\
\hline Milk & $9891^{\mathrm{a}} \pm 1515$ & $5907^{\mathrm{b}} \pm 469$ \\
Sale of dung and animals & $1794^{\mathrm{a}} \pm 270$ & $655^{\mathrm{b}} \pm 42$ \\
Total & $11685^{\mathrm{a}} \pm 1730$ & $6562^{\mathrm{b}} \pm 499$ \\
\hline
\end{tabular}

Means with different superscripts in a row are significantly different $(\mathrm{P}<0.05)$.

Total income, labour cost and total cost (including labour + concentrates + medicine + services) for both systems on daily basis for the herd are given in Table 7. This table gives the actual picture between two management systems. The total income minus total cost provided profit (including labour). However, the total cost excluding labour (i.e. total cost minus labour cost) was deducted from total income to obtain profit excluding labour since family labour was mostly used in the management system. Even though the income from 
dairying was higher $(\mathrm{P}<0.05)$ in the intensive farming system compared to semi-intensive system, the profits of both farming systems were not significantly different $(\mathrm{P}>0.05)$, as the costs (particularly labour cost) were very high under intensive system. However, it is interesting to note that the profit per day per herd without labour under intensive system was 1.6 times higher than that of semi-intensive system.

Table 7. Comparison of cost and benefits of including labour and excluding labour between dairy farming systems (Rs./day/herd)

\begin{tabular}{lcc}
\hline Cost/Benefit & Intensive & Semi-intensive \\
\hline Total cost (Rs.) /day & $552.56^{\mathrm{a}} \pm 46.89$ & $380.32^{\mathrm{b}} \pm 19.87$ \\
Total income (Rs.) /day & $389.49^{\mathrm{a}} \pm 57.70$ & $218.74^{\mathrm{b}} \pm 16.63$ \\
Labour cost (Rs.) /day & $444.93^{\mathrm{a}} \pm 32.86$ & $339.68^{\mathrm{b}} \pm 18.30$ \\
Profit (Rs.) /day & & \\
Including Labour & $-163.58^{\mathrm{a}} \pm 35.42$ & $-161.58^{\mathrm{a}} \pm 17.20$ \\
Excluding labour & $281.86^{\mathrm{a}} \pm 41.39$ & $177.61^{\mathrm{a}} \pm 13.27$ \\
\hline
\end{tabular}

Means with different superscripts in a row are significantly different $(\mathrm{P}<0.05)$.

Table 8 presents the cost benefit analysis between dairy management systems per day per AU .

Table 8. Cost benefit analysis between dairy management systems (Rs./day/AU)

\begin{tabular}{lrr}
\hline Cost/Benefit & Intensive & Semi-intensive \\
\hline Labour cost, Rs/d/AU & & \\
$\quad$ - Grass cutting & $96.26^{\mathrm{a}} \pm 9.63$ & $84.23^{\mathrm{a}} \pm 5.22$ \\
$\quad$ - Cleaning the shed & $11.51^{\mathrm{a}} \pm 1.25$ & $12.61^{\mathrm{a}} \pm 0.73$ \\
$\quad$ - Milking & $9.36^{\mathrm{a}} \pm 1.84$ & $9.47^{\mathrm{a}} \pm 0.72$ \\
$\quad$ - Sale of milk & $11.41^{\mathrm{a}} \pm 4.12$ & $14.70^{\mathrm{a}} \pm 1.43$ \\
$\quad$ - Total labour cost & $128.53^{\mathrm{a}} \pm 14.89$ & $121.01^{\mathrm{a}} \pm 6.44$ \\
Other cost, Rs/d/AU & & \\
$\quad$ - Concentrate, medicines & $26.45^{\mathrm{a}} \pm 4.45$ & $13.87^{\mathrm{a}} \pm 1.85$ \\
$\quad$ and services & & \\
Income, Rs./d/AU & & \\
$\quad$ - Milk & $84.55^{\mathrm{a}} \pm 10.01$ & $66.58^{\mathrm{a}} \pm 5.22$ \\
$\quad$ - Sale of dung and animals & $14.49^{\mathrm{a}} \pm 0.77$ & $7.09^{\mathrm{a}} \pm 0.23$ \\
Total Income & $99.04^{\mathrm{a}} \pm 10.58$ & $73.68^{\mathrm{a}} \pm 5.37$ \\
Profit & & \\
Including labour & & $-61.20^{\mathrm{a}} \pm 6.05$ \\
Excluding labour & $55.94^{\mathrm{a}} \pm 15.02$ & $59.81^{\mathrm{a}} \pm 3.98$ \\
\hline
\end{tabular}

Means with different superscripts in a row are significantly different $(\mathrm{P}<0.05)$.

According to Table 8, total cost of production, total income and profit from dairying was not different between two systems $(\mathrm{P}>0.05)$. However, when labour cost was not included in profit calculation, the mean net income received by the farmers under intensive system was higher compared to semi-intensive system even though the values were not significantly $(\mathrm{P}>0.05)$ different. Those are the net returns that a farmer gains for the labour spent (i.e. the daily wages for working in the farm), which are quite low compared to the regular price for daily labour (Rs. 550.00 per day) of the area. Thus if Rs. 450.00 is to be paid for labour, then the enterprise would end up with negative profits. 
In fact, the returns for labour would have been much worse had the expenditure for capital, depreciation, equipment and maintenance costs, etc. were included. Under these conditions, many farmers seem to continue their dairy operations only because of dearth of regular alternative employment opportunities for them in the vicinity. More and more dairy farmers are leaving the industry for alternative employment as it is not a profitable venture in the country.

\section{CONCLUSIONS}

This study reveals that most of the farmers engaged in dairying as a part time activity and expected an additional income from dairying. All these farmers were vegetable farmers and continued to have dairy animals as a valuable supply of much needed cattle manure and milk. In addition, family labour was used for both vegetable cultivation and for dairy farming where alternative employment opportunities were scanty. The mean net income received by the farmers under intensive system was higher compared to semi-intensive system due to slightly larger herd size, higher proportion of purebred animals and better feeding practices used under intensive system compared to semi-intensive system under vegetable based system in Welimada area. In both intensive and semi-intensive cattle management systems, there were farms which had zero milk in some periods of the year, partly because of small herd size, lack of milking cows and shorter lactation lengths. Therefore it is necessary to implement a good extension service in Welimada area to educate the farmers to overcome these problems. Upgrading of animals can also lead to higher production in the herd. Establishment of good quality pasture and fodder in the contour lines of the farm and fodder legumes in the fence line would help to reduce the labour cost for grass cutting and expenses for concentrate feeding while increasing the profit. Utilization of naturally available feed resources, vegetable waste, rice straw, Jak and Glyricidia can also increase the milk production of animals and can reduce the cost of production in the area. Introduction of efficient manure management practices can also lead to higher income generation and higher profits in both management systems under village based farming systems in Welimada area.

\section{ACKNOWLEDGEMENTS}

The authors acknowledge the assistance provided by the Staff of Government Veterinary Office, Welimada; Mr. K.M. Dhayalal and staff of Ruvansiri Enterprises, Welimada; Manager and Staff of MILCO Chilling Centre, Welimada and all dairy farmers involved in this study.

\section{REFERENCES}

Bandara, B.H.W.M.U.S. (2000). The current status of smallholder dairy systems in Sri Lanka. Available at http://www. daph.gov.lk.

Department of Censes and Statistics (2006). Socioeconomic Indicators for Selected 119 Divisional Secretary's Divisions, Sri Lanka.

Dikken, D. G. (1997). Smallholder dairy farming in Sri Lanka: Labour allocation and access to feed resources. Master of Science Dissertation, Animal Production Systems, Waganingen Agricultural University, the Netherlands. 
Epidemiological Report, (2008). Veterinary Office, Welimada, Sri Lanka

Hitihamu, H.M.S.J.M., Samantha, N.P.G. and Rathnayake, R.M.G.K.B. (2007). Factors affecting the cost of production of milk. HARTI Newsletter - Hector Kobbekaduwa Agrarian Research and Training Institute of Sri Lanka. 32 (1 \& 2): p. 3.

Jayaweera, T.S.P., Ruwandeepika, H.A.D. and Gajanayake, T.N. (2003). Analysis of the cost of milk production in Rathnapura district. The Sri Lanka Vet. J. 50 (1), 33- 34.

Livestock Statistics (2009) Ministry of Animal Production and Health. Colombo, Sri Lanka.

Mahipala M.B.P., Gunaratne L.H.P., Bandara, A.B. and Peiris, B. I. (2006). Farm level economics, services and constraints of cattle farming in small holder cattle farming systems in Up-Country Wet-Zone, Sri Lanka. Proceedings of International Conference on Livestock Services China, 242-252.

Mahipala, M.B.P. and Gunaratne, L.H.P. (2003). Comparison of Cattle Farming Systems in Upcountry Wet Zone: Cattle management, Social structure and Involvement in Cattle Farming. Sri Lankan J. of Animal Prod. 2 (1), 41-55.

Ministry of Livestock Development and Estate Infrastructure. (2000). Policy strategy for dairy industry. Ministry of Livestock Development and Estate Infrastructure, Colombo, Sri Lanka.

Perera, M.M.D.S.N., Seresinhe, T and Seresinhe, Y.D.J.D.W. (2004). Study of cattle production performance under smallholder farms in the Pelwatta area of Monaragala district. Proceedings of the 60th Annual Sessions of Sri Lanka Association for the Advancement of Science.

Progress Review Report, Provincial Department of Animal Production and Health, Uva 2008 .

Rathnayake, D., Abeygunawardhana, H., Jayathilaka, M.W.A.P. and Abeywansa, W.D. (1992). Identification of distinctive cattle farming systems in Sri Lanka and Estimation of their production cost. Trop. Agric. Res. 4, 225 -244.

Ranaweera, N.F.C. (2007). Improved market access and smallholder dairy farmer participation for sustainable dairy development. Lessons Learned. Sri Lanka.

SAS, (1998).SAS User's Guide: Statistics. Statistical Analysis System Institute, Inc., Cary, NC.

Serasinghe, R.N., Mahipala, M.B.P. and Gunaratne, L.H.P. (2003). Comparison of Stochastic Frontier Analysis (SFA) and Data Envelopment Analysis (DEA) to evaluate technical efficiency: Illustrated by efficiency analysis of cattle farming systems in Up-Country Wetzone of Sri Lanka. J. Trop. Agric. Res. 15, 217-225.

Veterinary Investigation Report (2009). Veterinary Investigation Centre, Badulla.

Zemmelink,G., Premaratne, S., Ibrahim, M. N. M. and Leegwater, P. H. (1999). Feeding of dairy cattle in the forest garden farms of Kandy, Sri Lanka. Trop. Animal Health and Prod. 31, 307-319. 